\title{
Commentary Acute kidney injury in burns: a story of volume and inflammation Kirsten Colpaert and Eric A Hoste
}

Intensive Care Unit, Ghent University Hospital, De Pintelaan 185, 9000 Gent, Belgium

Corresponding author: Eric Hoste, eric.hoste@ugent.be

Published: 25 November 2008

Critical Care 2008, 12:192 (doi:10.1186/cc7106)

This article is online at http://ccforum.com/content/12/6/192

(c) 2008 BioMed Central Ltd

See related research by Steinvall et al., http://ccforum.com/content/12/5/R124

\begin{abstract}
Acute kidney injury occurs in approximately one-quarter to onethird of patients with major burn injury. Apart from the usual suspects - such as older age, severity of burn injury, sepsis and multiple organ dysfunction - volume overload probably has an important role in the pathogenesis of acute kidney injury.
\end{abstract}

Steinvall and collaborators present the third study on acute kidney injury (AKI) defined by the RIFLE classification in patients with major burn injury [1]. AKI was formerly only considered relevant when there was a need for renal replacement therapy. We now know that moderate decreased kidney function also has an impact on patient outcomes [2]. Only since the first consensus definition for AKI, however - the RIFLE classification [3], which was modified later into the AKI staging system [4] - are we able to truly evaluate the epidemiology of $\mathrm{AKI}$ in diverse cohorts of patients. AKI has a population incidence greater than that of acute respiratory distress syndrome, and is comparable with that of sepsis [5]. The incidence rate in a general intensive care unit is on average $30 \%$ to $40 \%$, but this rate varies according to the specific cohort.

Despite the limitation that the study by Steinvall and colleagues includes only 127 patients with major burns, the study has several strengths. The authors present a very thorough evaluation of $\mathrm{AKI}$, including many possible confounders for AKI. The cohort of patients also seems representative for burn unit patients in the western world [1].

What did these studies learn, and how does the study of Steinvall and colleagues relate to the other two studies on this subject - those by Lopes and colleagues $(n=126)$ [6] and by Coca and colleagues $(n=304)$ [7]? Importantly, all three studies confirmed findings in other cohorts that increasing RIFLE class was associated with a stepwise increase of mortality. There was a large difference, however, in the incidence of AKI between the studies of Coca and colleagues and of Steinvall and colleagues $(26.6 \%$ and $24.4 \%$, respectively) compared with that of Lopes and colleagues (35.7\% incidence). This difference cannot be explained by differences in baseline characteristics, such as age and total burned surface area. Other explanations should therefore be explored.

The study by Lopes and colleagues classifies patients according to the original RIFLE classification, on both urine output and serum creatinine concentration [6]. This is in contrast to the studies by Steinvall and colleagues and Coca and colleagues, which only use serum creatinine $[1,7]$. Especially in burn patients, the serum creatinine concentration may underestimate kidney function. The cornerstone in acute burn care therapy is large-volume resuscitation to compensate for the massive fluid losses and decreased effective circulating volume. This may lead to hemodilution, and to false low serum creatinine concentrations that do not reflect true kidney function. Catabolism, leading to loss of muscle mass, may also contribute to low serum concentrations. As the muscles are the source of creatinine, less muscle mass will result in lower serum creatinine concentrations for the same glomerular filtration rate [8]. In other words, the two studies that only used creatinine criteria may have underestimated the true incidence of AKI.

Steinvall and colleagues also report interesting data on the occurrence of $\mathrm{AKI}$ in relation to other organ dysfunctions. They found that approximately one-half of patients, especially those with more severe burn injury, developed AKI during the first week; the other half developed AKI during the next week. AKI was preceded, however, by other organ dysfunctions or sepsis in the majority of patients [1]. In burn injury, decreases of effective circulating volume are maximal during the first 8 hours. Apparently, the burn shock resuscitation schedule used was successful in preventing AKI in this very early 
phase of burn shock. So when burn shock is not the cause of $\mathrm{AKI}$, what else is?

This question brings us to the shift in paradigm on the pathophysiology of AKI. While formerly hypoperfusion and ischemia of the kidneys were thought the main causes of AKI in sepsis, there are now more data indicating that renal perfusion is not decreased in sepsis [9]. Instead, inflammation and apoptosis are probably playing an important role [10]. Data on renal perfusion in burn injury are lacking, but the present findings suggest that renal ischemia is also less relevant, at least in the acute phase of burn injury. Furthermore, major burn trauma patients differ from other intensive care trauma patients by experiencing an inflammatory response that is often more severe, and lasts much longer, compared with other trauma patients [11].

Another factor that may contribute to $\mathrm{AKI}$ in a second stage after burn shock is that volume resuscitation leads to development of intra-abdominal hypertension and abdominal compartment syndrome [12,13].

This brings us to the issue of the optimal burn resuscitation schedule. Most units use Ringer's lactate and the Parkland resuscitation schedule $(4 \mathrm{ml} / \mathrm{body}$ weight $(\mathrm{kg}) / \%$ total burned surface area). Most patients receive more fluids, however even volumes up to $6 \mathrm{ml} / \mathrm{kg} /$ total burned surface area have been reported [14]. Other resuscitation endpoints, or other types of fluids - such as hypertonic saline or colloids - may decrease the volume, decrease the incidence of intraabdominal hypertension and abdominal compartment syndrome, and decrease AKI [15-17].

In conclusion, $\mathrm{AKI}$ is also an important complication in burn patients as it is frequent and it is associated with mortality. Inflammation and volume overload play an important role in the pathogenesis of AKI. After decades of care for burn patients, therefore, we definitely need good studies into the optimal volume resuscitation strategy.

\section{Competing interests}

The authors declare that they have no competing interests.

\section{References}

1. Steinvall I, Bak Z, Sjoberg F: Acute kidney injury is common, parallels organ dysfunction or failure, and carries appreciable mortality in patients with major burns: a prospective exploratory cohort study. Crit Care 2008, 12:R124.

2. Levy EM, Viscoli CM, Horwitz RI: The effect of acute renal failure on mortality. A cohort analysis. JAMA 1996, 275:14891494.

3. Bellomo R, Ronco C, Kellum JA, Mehta RL, Palevsky P, and the ADQI workgroup: Acute renal failure - definition, outcome measures, animal models, fluid therapy and information technology needs: the Second International Consensus Conference of the Acute Dialysis Quality Initiative (ADQI) Group. Crit Care 2004, 8:R204-R212.

4. Mehta RL, Kellum JA, Shah SV, Molitoris BA, Ronco C, Warnock DG, Levin A: Acute Kidney Injury Network (AKIN): report of an initiative to improve outcomes in acute kidney injury. Crit Care 2007, 11:R31.
5. Hoste EAJ, Schurgers M: Epidemiology of AKI: how big is the problem? Crit Care Med 2008, 36:S1-S4.

6. Lopes JA, Jorge S, Neves FC, Caneira M, da Costa AG, Ferreira AC, Prata MM: An assessment of the RIFLE criteria for acute renal failure in severely burned patients [letter]. Nephrol Dial Transplant 2007, 22:285.

7. Coca SG, Bauling P, Schifftner T, Howard CS, Teitelbaum I, Parikh CR: Contribution of acute kidney injury toward morbidity and mortality in burns: a contemporary analysis. $\mathrm{Am} J$ Kidney Dis 2007, 49:517-523.

8. Hoste EA, Damen J, Vanholder RC, Lameire NH, Delanghe JR, Van den Hauwe K, Colardyn FA: Assessment of renal function in recently admitted critically ill patients with normal serum creatinine. Nephrol Dial Transplant 2005, 20:747-753.

9. Langenberg C, Wan L, Egi M, May CN, Bellomo R: Renal blood flow in experimental septic acute renal failure. Kidney Int 2006, 69:1996-2002.

10. Wan L, Bellomo R, Di Giantomasso D, Ronco C: The pathogenesis of septic acute renal failure. Curr Opin Crit Care 2003, 9: 496-502.

11. Jeschke MG, Mlcak RP, Finnerty CC, Norbury WB, Gauglitz GG, Kulp GA, Herndon DN: Burn size determines the inflammatory and hypermetabolic response. Crit Care 2007, 11:R90.

12. Tuggle D, Skinner S, Garza J, Vandijck D, Blot $S$ : The abdominal compartment syndrome in patients with burn injury. Acta Clin Belg 2007, 1:136-140.

13. Ivy ME, Atweh NA, Palmer J, Possenti PP, Pineau M, D' Aiuto M: Intra-abdominal hypertension and abdominal compartment syndrome in burn patients. J Trauma 2000, 49:387-391.

14. Blumetti J, Hunt JL, Arnoldo BD, Parks JK, Purdue GF: The Parkland formula under fire: is the criticism justified? J Burn Care Res 2008, 29:180-186.

15. Oda J, Ueyama M, Yamashita K, Inoue T, Noborio M, Ode $\mathrm{Y}$, Aoki $Y$, Sugimoto $\mathrm{H}$ : Hypertonic lactated saline resuscitation reduces the risk of abdominal compartment syndrome in severely burned patients. J Trauma 2006, 60:64-71.

16. O'Mara MS, Slater H, Goldfarb IW, Caushaj PF: A prospective, randomized evaluation of intra-abdominal pressures with crystalloid and colloid resuscitation in burn patients. J Trauma 2005, 58:1011-1018.

17. Arlati S, Storti E, Pradella V, Bucci L, Vitolo A, Pulici M: Decreased fluid volume to reduce organ damage: a new approach to burn shock resuscitation? A preliminary study. Resuscitation 2007, 72:371-378. 